\title{
A synthesis of research needs for improving the understanding of atmospheric mercury cycling
}

\author{
Leiming Zhang ${ }^{1}$, Seth Lyman ${ }^{2}$, Huiting Mao ${ }^{3}$, Che-Jen Lin ${ }^{4}$, David A. Gay ${ }^{5}$, Shuxiao Wang ${ }^{6}$, Mae Sexauer Gustin ${ }^{7}$, \\ Xinbin Feng ${ }^{8}$, and Frank Wania ${ }^{9}$ \\ ${ }^{1}$ Air Quality Research Division, Science and Technology Branch, Environment and Climate Change Canada, \\ Toronto, ON, Canada \\ ${ }^{2}$ Department of Chemistry and Biochemistry, Utah State University, Vernal, UT, USA \\ ${ }^{3}$ Department of Chemistry, State University of New York College of Environmental Science and Forestry, Syracuse, NY, USA \\ ${ }^{4}$ Center for Advances in Water and Air Quality, Lamar University, Beaumont, TX, USA \\ ${ }^{5}$ National Atmospheric Deposition Program, University of Illinois, Champaign, IL, USA \\ ${ }^{6}$ School of Environment, Tsinghua University, Beijing, China \\ ${ }^{7}$ Department of Natural Resources and Environmental Science, University of Nevada, Reno, NV, USA \\ ${ }^{8}$ Institute of Geochemistry, Chinese Academy of Sciences, Guiyang, China \\ ${ }^{9}$ Department of Physical and Environmental Sciences, University of Toronto Scarborough, Toronto, ON, Canada
}

Correspondence to: Leiming Zhang (leiming.zhang@canada.ca)

Received: 24 April 2017 - Discussion started: 2 May 2017

Revised: 28 June 2017 - Accepted: 6 July 2017 - Published: 28 July 2017

\begin{abstract}
This synthesis identifies future research needs in atmospheric mercury science, based on a series of review papers, as well as recent developments in field data collection, modeling analysis, and emission assessments of speciated atmospheric mercury. Research activities are proposed that focus on areas that we consider important. These include refinement of mercury emission estimations, quantification of dry deposition and air-surface exchange, improvement of the treatment of chemical mechanisms in chemical transport models, increase in the accuracy of oxidized mercury measurements, better interpretation of atmospheric mercury chemistry data, and harmonization of network operation. Knowledge gained in these research areas will significantly improve our understanding of atmospheric cycling from local to global scales.
\end{abstract}

\section{Introduction}

Knowledge of atmospheric mercury $(\mathrm{Hg})$ cycling processes and accurate mass balances on local, regional, and global scales is needed to assess $\mathrm{Hg}$ impacts on humans, animals, and ecosystems, and to establish $\mathrm{Hg}$ emission con- trol policies. A series of review papers, published in a special issue of Atmospheric Chemistry and Physics (http:// www.atmos-chem-phys.net/special_issue377.html), summarize the knowledge gained from decades of research on atmospheric $\mathrm{Hg}$, operationally defined as gaseous elemental $\mathrm{Hg}$ (GEM), gaseous oxidized $\mathrm{Hg}$ (GOM) and particulatebound $\mathrm{Hg}$ (PBM).

Current methods for measurement and model interpretation of the three forms of $\mathrm{Hg}$ in the atmosphere were reviewed in Gustin et al. (2015). They revealed potential large measurement uncertainties and associated important implications for refining existing measurement methods, modelmeasurement comparisons, model development and trend analysis. Sampler designs for passive GEM sampling were reviewed in McLagan et al. (2016), and the suitability of these devices for measuring high and low GEM concentrations was identified. Mercury transformation mechanisms and speciation profiles for $\mathrm{Hg}$ formed in and released from flue gases of coal-fired boilers, non-ferrous metal smelters, cement plants, iron and steel plants, waste incinerators and biomass burning were documented in Zhang et al. (2016a). Worldwide measurements of $\mathrm{Hg}$ spanning the past 4 decades were reviewed in Mao et al. (2016) together with the mecha- 
nisms driving the observed spatiotemporal variations of speciated $\mathrm{Hg}$ in various environments including oceans, continents, high elevation, the free troposphere, and low to high latitudes. Current knowledge of $\mathrm{Hg}$ dry deposition was reviewed in Wright et al. (2016), including dry deposition algorithms used in chemical transport models and at monitoring sites, measurement methods and quantification of dry deposition of oxidized $\mathrm{Hg}$, and $\mathrm{Hg}$ in litterfall and throughfall. The same study also explored the geographical variations of $\mathrm{Hg}$ deposition as well as the relative importance of dry and wet deposition. A global observational flux database of the atmosphere-surface exchange of GEM was developed and the implication of the flux data to global $\mathrm{Hg}$ budgets was discussed in Zhu et al. (2016). Receptor-based source apportionment studies using speciated $\mathrm{Hg}$ were summarized in Cheng et al. (2015a), and studies related to speciated $\mathrm{Hg}$ in China were reviewed in Fu et al. (2015).

Recommendations for future research needs based on the aforementioned review articles are summarized below, and the discussion here is extended further to include topics not included in the special issue, but closely linked to the understanding of atmospheric $\mathrm{Hg}$ cycling. This synthesis is not aimed to cover all research needs of atmospheric $\mathrm{Hg}$, but to provide directions guiding future research. Other recommendations and knowledge gaps can also be found in a recent mercury science assessment conducted in Canada which summarized scientific findings from research undertaken in the past 20 years focusing on the Canadian environment (ECCC, 2017).

\section{Recommendations}

\subsection{Mercury emission}

Emission inventories used in chemical transport models (CTMs) are prepared using known anthropogenic sources and highly empirically parameterized natural sources. Existing emission inventories are thought to be relatively accurate for anthropogenic emission source categories such as energy and industrial sectors in the United States and Europe, but with large uncertainties for other anthropogenic sources, and even larger uncertainties for natural sources and re-emission estimation (Pacyna et al., 2016).

To improve estimation of mercury emission from anthropogenic sources, several measurement studies are recommended (Pacyna et al., 2016; UNEP, 2013; Zhang et al., 2016a). These include (1) measurements of mercury behavior across newly employed air pollution control devices (APCDs), e.g., wet electrostatic precipitators (WESPs) for coal-fired power plants, flue gas desulfurization (FGD) systems, and novel mercury reclaiming towers (MRTs) for non-ferrous metal smelters; (2) continuous measurements of mercury transformation and speciation under different operational conditions, e.g., raw mill on/off modes and the whole cycle of fly ash circulations in cement plants; (3) measurements of mercury transformation and speciation in flue gases from sources (e.g., iron and steel plants, waste incinerators) and assessing the influence of raw materials on mercury transformation and speciation; (4) continuous measurements of mercury emission from sources with large fluctuation (e.g., waste incinerators, crematories), which can be achieved through mercury flow analysis and statistical methods for the inventory developments of these sources; (5) measurements of mercury emission factors and speciation of potential large sources, e.g., mobile oil combustion, reutilization of by-products (e.g., fly ash, waste acid), which will become potential large sources once mercury emissions from current dominant sources are controlled; and (6) mercury emission from artisanal and small-scale gold mining activities in developing countries, a source category that has been poorly characterized. Anthropogenic releases of $\mathrm{Hg}$ to freshwater also need to be better estimated (Liu et al., 2016; Kocman et al., 2017; UNEP, 2013) since Hg in waterbodies can be released into atmosphere through the air-surface exchange processes.

Natural emissions include those from geogenic sources as well as from re-emission of previously deposited mercury. To improve estimation of mercury emission from natural sources, a global database of GEM flux from different land covers and geogenic sources could be developed, similar to those done by Ericksen et al. (2006) and Hartman et al. (2009). Another way to approach this would be to do a literature review and compile papers that have identified dominant mechanisms and developed algorithms that can be applied in models (Eckley et al., 2011, 2016; Hartman et al., 2009). Dominating factors include soil concentration of $\mathrm{Hg}$, solar radiation, temperature, soil moisture, and precipitation (Briggs an Gustin, 2013). GEM evasion from the sea surface is an important source (Pacyna et al., 2016), and air-sea $\mathrm{Hg}$ flux could be modeled using parameters (e.g., temperature, wind speed) known to influence this exchange. It is important to note that there is little work on GOM flux from any surface due to analytical challenges associated with detecting ultra-trace quantity of GOM at sufficiently high temporal resolution. The emission quantity and speciation of $\mathrm{Hg}$ from wildfires are not well characterized due to a general lack of observational data (Webster et al., 2016). The data presented in Friedli et al. $(2003,2009)$ provided preliminary estimates based on aircraft measurement and a satellite constrained bottom-up methodology. Limited investigations have suggested that the emission speciation is primarily GEM, and the emission quantity can be modeled based on the $\mathrm{Hg}$ content in different parts of tree biomass. It may also be investigated through plume or receptor measurement and modeling analysis. Mercury emission from geogenic sources such as geothermal activities, volcanic eruptions, and plate tectonic movements needs to be better quantified.

Estimation of emissions from area sources, e.g., urban areas, natural sources, and large contaminated sites such as 
abandoned mercury mines or artisanal gold mining operations, is important for these can constitute significant sources. For example area emissions were shown to be similar to stack emissions at a Nevada gold mine (Eckley et al., 2011). Methods for the identification, localization and characterization of such mercury sources to the atmosphere are required to support efforts to further reduce mercury emissions globally. Once identified and substrate concentrations and meteorological conditions are known for contaminated areas, previously developed algorithms or models could be used to refine the emission estimates and then evaluated with field measurements.

Passive air samplers may play a role in the identification of the above-mentioned area sources and in the quantification of emissions emanating from them. In particular, the cost and simplicity of passive sampling allows extensive networks of samplers to be deployed to record average concentrations over extended time periods and at high spatial resolution (Huang et al., 2014; McLagan et al., 2016). Novel passive sampling techniques for gaseous mercury (both GEM and GOM) will facilitate highly resolved, spatial mapping of time-averaged mercury air concentration in and around area sources of mercury to the atmosphere, both natural and anthropogenic. Development of numerical models for emission source strength estimate that can utilize long-term data obtained from passive samplers over a large spatial coverage will also be an important future task.

Constraining the contribution of different sources of mercury to the atmospheric burden might be aided by the measurement of the isotopic composition of mercury in the atmosphere (R. Sun et al., 2016). Presently, characterizing the isotopic composition of atmospheric mercury is challenging and has only been accomplished at a small scale, because of the need to collect sufficient mercury mass for isotopic analysis (e.g., Blum and Johnson, 2017; Fu et al., 2016; Yu et al., 2016). Such measurements may be greatly facilitated by passive air samplers that can quantitatively sample mercury from the atmosphere for extended time periods. In particular, with a global network of passive air samplers, it might be possible to assess the average isotopic composition of the global atmosphere, which in turn may allow an assessment of the relative importance of different types of mercury emissions. An important need is to investigate the potential for isotopic fractionation during the passive sampling process.

\subsection{Dry deposition and air-surface exchange}

Consistent and reliable methods for determining the dry deposition of mercury compounds is critically needed since this process dominates the mercury input into many ecosystems. Current methods rely on measurement of atmospheric concentrations, combined with modeled deposition velocities, to estimate dry deposition fluxes (Zhang et al., 2016b). Further refinement of existing methods for directly measuring dry deposition fluxes is needed (Huang et al., 2014).
The most common approach for measuring dry deposition flux of oxidized mercury (GOM and PBM) is using devices with surrogate surfaces collecting the oxidized mercury (Wright et al., 2016). However, surrogate surfaces may not accumulate the same amount of oxidized $\mathrm{Hg}$ as natural surfaces. A surrogate surface would collect the same amount of oxidized mercury over different land uses at the same location assuming the same aerodynamic and chemical conditions, while in theory dry deposition flux can vary by a factor of 2 or larger over different land uses (Zhang et al., 2016b). Dry deposition algorithms validated using such field flux measurements have uncertainties of a similar magnitude. More complicated methods, such as the relaxed eddy accumulation method (Skov et al., 2006; Zhu et al., 2015a, b), may provide more accurate flux data.

For GEM, bidirectional flux exchange makes the surrogate surface flux measurements meaningless. No surrogate surface can simulate the canopy since the majority of GEM uptake is by foliage and likely an active process by the vegetation. After uptake, GEM could be oxidized and stored in the foliage (Wang et al., 2016; Yu et al., 2016) and part of the oxidized mercury can be reduced and re-emitted back to the air (Gustin, 2011). Gradient methods also have large uncertainties due to (1) lack of homogeneity of underlying surfaces, and (2) small gradients compared to instrumental detection accuracy. A modified gradient method is worth considering for measuring GEM flux (Wu et al., 2015). Relaxed eddy accumulation would work, but is a complex measurement technique (see Ostwalder et al., 2016). Concurrent gradient measurements of GEM and other well-known pollutant species (such as $\mathrm{O}_{3}$ ) can provide a sense of data quality. Presently, GEM flux observations are made in relatively short-term campaigns (Edwards and Howard, 2013). Longerterm measurements are needed to adequately observe the variation in seasonal flux variation and the influence of environmental factors. This has been done in laboratory studies with chambers and some comparison with field measurements (see Eckley et al., 2011; Miller et al., 2011; Miller and Gustin, 2013).

Concurrent measurements of $\mathrm{Hg}$ fluxes using different methods (e.g., gradient measurements), litterfall, throughfall and soil $\mathrm{Hg}$ content provide more complete information when combined with model estimates (Graydon et al., 2012). Individual data sets can have large uncertainties. With a combined data set, uncertainty ranges can be quantified and model validation/improvement can be done with more confidence (Wright et al., 2016; Zhang et al., 2016b). Such a combined campaign would be useful for quantifying the flux to forests, which are a potentially large sink of mercury worldwide. The geospatial coverage of GEM flux data is highly heterogeneous, and more field observations are needed in South America, South Asia, Africa, Australia and the polar regions (Zhu et al., 2016).

Other research advancements that can improve our understanding of flux exchanges include developing a fast- 
response detection technique at sufficiently high sensitivity to reduce the uncertainty of flux measurement, investigating kinetic parameters of $\mathrm{Hg}$ transformation (redox and coordination chemistry) in soil and on surfaces to fundamentally understand bidirectional GEM exchange, and developing mechanisms describing physicochemical and biological processes contributing to evasion and deposition processes. The quantity of GEM air-surface exchange at global scales can then be reassessed using models that better describe processes.

\subsection{Chemical mechanisms}

Due to the limited knowledge on the chemical forms of oxidized $\mathrm{Hg}$ and its ultra-trace concentrations below the detection limit of existing instruments, both monitoring networks and CTMs use the operationally defined oxidized $\mathrm{Hg}$ (GOM and PBM). The chemistry of atmospheric $\mathrm{Hg}$ has long been regarded as a major source of CTM uncertainties (Lin et al., 2006; Pongprueksa et al., 2008; Subir et al., 2011, 2012) resulting in widely varying treatments of GEM oxidation in CTMs (Ariya et al., 2015; De Simone et al., 2014). Many oxidation reactions currently employed in CTMs or published studies are considered implausible based on kinetic and ab initio thermodynamic equations (Balabanov et al., 2005; Calvert and Lindberg, 2005; Dibble et al., 2012), such as the following,

$$
\begin{aligned}
& \mathrm{Hg}+\mathrm{Br}_{2} \rightarrow \mathrm{HgBr}_{2} \\
& \mathrm{Hg}+\mathrm{Cl}_{2} \rightarrow \mathrm{HgCl}_{2} \\
& \mathrm{Hg}+\mathrm{BrO} \rightarrow \mathrm{BrHgO} \\
& \mathrm{Hg}+\mathrm{HOOH} \rightarrow \mathrm{Hg}(\mathrm{OH})_{2} \\
& \mathrm{Hg}+\mathrm{O}_{3} \rightarrow \text { products } \\
& \mathrm{Hg}+\mathrm{OH} \rightarrow \text { products } \\
& \mathrm{Hg}+\mathrm{NO}_{3} \rightarrow \text { products, }
\end{aligned}
$$

but could be facilitated by heterogeneous reactions or complex reactions with other constituents in the atmosphere (T. Dibble, personal communication, 2017). Gas-particle partitioning between GOM and PBM in CTMs is mostly oversimplified (see a summary in Ariya et al., 2015). A fundamental understanding of the chemistry driving atmospheric $\mathrm{Hg}$ cycling is needed, which requires GOM speciation measurements and laboratory studies on multiphase redox kinetics.

While technical breakthroughs of GOM speciation measurements are gradually emerging (see Deeds et al., 2015; Gustin et al., 2015; Lyman et al., 2016), quantum computational tools and laboratory experiments could shed light on the potential reactions and provide theoretical values for model interpretation of atmospheric $\mathrm{Hg}$ chemistry. Dibble et al. (2012) used quantum calculations to determine the stability of GOM compounds likely to be formed in the Brinitiated oxidation of GEM and demonstrated stable products, $\mathrm{HgBrY}$, forming from $\mathrm{HgBr}$ reacting with $\mathrm{NO}_{2}, \mathrm{HO}_{2}$,
$\mathrm{ClO}$, and $\mathrm{BrO}$, as well as little dependence of the bond strength of $X \mathrm{Hg}-Y(X=\mathrm{Br}, \mathrm{Cl})$ on halogen identity. In the first kinetic study of $\mathrm{BrHg}+\mathrm{NO}_{2}$ and $\mathrm{BrHg}+\mathrm{HOO}$, Jiao and Dibble (2017) computationally determined the rate constants and product yields for these two reactions. Incorporating results from studies like these in atmospheric models is likely to cause significant changes in predicted rates of GEM oxidation in different geographical regions and various parts of the atmosphere. A recent modeling study (Horowitz et al., 2017) suggested that applying those kinetic data in chemical transport models can be consequential to simulations of the spatiotemporal variability of GOM concentrations and deposition. A new study (Ye et al., 2017), which was recently submitted, evaluated a regional chemical transport model (CMAQ) modified by implementing a $\mathrm{Hg}$ and $\mathrm{Br}$ chemical mechanism that included the most up-to-date kinetic data and reactions (Ye et al., 2016) and constrained by an observed vertical profile of BrO. They found that the modified CMAQ-Hg could capture significantly greater seasonal and diurnal variations of GEM, GOM and PBM that the default version failed to do and simulate $\mathrm{Hg}$ wet and dry deposition in better agreement with observations or observationbased estimates. Moreover, calculated product yields could provide directions and guidance for laboratory experiments. Quantum chemical computation can in theory also be extended to studying the kinetics of aqueous- and solid-phase reactions, which could address multiphase redox chemistry. However, this remains quite challenging as it is very difficult to determine the geometries of aqueous and solid compounds among a multitude of other issues.

Research areas needed to improve the understanding of $\mathrm{Hg}$ cycling include (Ariya et al., 2015; Gustin et al., 2015; Solis et al., 2017; Subir et al., 2011, 2012; G. Y. Sun et al., 2016a): (1) primary oxidation mechanisms responsible for $\mathrm{Hg}$ removal from the atmosphere using measurement and quantum computation approaches; (2) $\mathrm{Hg}$ isotopic fractionation of gaseous- and aqueous-phase redox processes in air, water and soil; (3) interactions between various $\mathrm{Hg}$ compounds and particles in aqueous and gaseous phases; (4) information on mercury cycling in the upper troposphere and lower stratosphere; and (5) mechanism and kinetics of $\mathrm{Hg}$ (II) reduction in natural water and atmospheric droplets - in particular, the agents responsible for $\mathrm{Hg}$ (II) reduction under realistic environmental conditions.

\subsection{Field measurements of speciated mercury}

A growing body of research has shown that the only commercially available instrument capable of distinguishing between GEM, GOM and PBM (the Tekran 2537/1130/1135 speciation system) exhibits a low bias in measuring GOM, and a large uncertainty in measurements of PBM (Cheng and Zhang, 2017; Gustin et al., 2013; Lyman et al., 2016; Rutter and Schauer, 2007; Talbot et al., 2011). Ozone (Lyman et al., 2010; McClure et al., 2014), water vapor (Gustin et 
al., 2013; Huang and Gustin, 2015; McClure et al., 2014), and perhaps some other atmospheric constituents (Lyman et al., 2016) interfere with GOM measurements. Bias in $\mathrm{KCl}$ coated denuder-based GOM measurements varies with season, time of day, and chemical and meteorological conditions (Gustin et al., 2016; Huang and Gustin, 2015; Lyman et al., 2016; McClure et al., 2014), and current scientific understanding of GOM and PBM dynamics and chemistry is based, in part, on these biased measurements. Improved measurement methods are needed to re-establish and solidify scientific understanding of GOM and PBM sources, transport and fate in the atmosphere.

It is recommended when developing or improving measurement techniques that researchers consider the following: (1) reliable, routine, and reproducible calibration in laboratory and field conditions; (2) ability to capture GOM and PBM without significant measurement bias, or at least with a bias that is well characterized; and (3) ability to distinguish quantitatively between GOM and PBM. It is also desirable to identify and quantify individual oxidized mercury compounds, although this may be changing for operational purposes.

Measurement of ambient GOM at sub-pptv levels is challenging. Careful calibration under field measurement conditions is critical to understanding these biases and, potentially, correcting for them. Permeation tube-based methods have been used by several groups for GOM calibration (Finley et al., 2013; Huang and Gustin, 2015; Jones et al., 2016; Lyman et al., 2010; McClure et al., 2014), including an automated calibrator (Lyman et al., 2016), but other methods have been developed for high-concentration GOM calibration (e.g., Thermo model 81i and Tekran model 3310/3321) and could be adapted for ambient levels of GOM. Regardless of the method used, all future measurements of GOM should incorporate routine calibration in ambient air.

Cation-exchange membrane-based GOM collection methods have been explored as an alternative to denuder methods (Huang and Gustin, 2015; Huang et al., 2013). Air is drawn through the membranes, and oxidized mercury compounds are captured while other atmospheric constituents, including GEM, pass through. Membranes are then analyzed for total mercury content via standard methods. Limited studies in laboratory and ambient air have indicated that cationexchange membranes may exhibit bias for selected $\mathrm{Hg}$ compounds under atmospheric conditions (Gustin et al., 2016; Huang and Gustin, 2015). Direct measurement of GOM with cation-exchange membranes requires long sampling times (of the order of 1-2 weeks), but alternative collection configurations or materials could alleviate this concern.

Differential measurements that use quartz wool (Ambrose et al., 2015; Lyman and Jaffe, 2012; Slemr et al., 2016) or cation-exchange membranes (Ambrose et al., 2015; Gratz et al., 2015) to selectively trap GOM have provided GOM measurements with high temporal resolution. These methods currently have high detection limits (about $100 \mathrm{pg} \mathrm{m}^{-3}$;
Ambrose et al., 2015), but modifications could possibly improve detection. Quartz wool appears to work poorly as a GOM collection material in high-humidity environments (Ambrose et al., 2013, 2015). Other collection methods for GOM have been explored, notably nylon membranes (Gustin et al., 2013; Huang and Gustin, 2015), zirconia (Urba et al., 2017), and PTFE chips (Deeds et al., 2015). Nylon membranes do not quantitatively capture GOM, but have been shown to be useful for thermal desorption techniques (discussed below; Huang and Gustin, 2015). Zirconia shows promise at collecting GOM with low interference from ozone and water vapor (Urba et al., 2017). Some other collection surfaces have been explored as well (Lyman et al., 2007; Rutter et al., 2008; Urba et al., 2017).

Two types of methods under development focus on identifying individual oxidized mercury compounds in the atmosphere. The first is mass spectrometry (MS)-based methods. Deeds et al. (2015) described an atmospheric-pressure chemical ionization MS that can identify $\mathrm{HgBr}_{2}$ and $\mathrm{HgCl}_{2}$ in the atmosphere after preconcentration and thermal desorption, though interference from other atmospheric constituents made identification somewhat ambiguous in ambient air samples. Jones et al. (2016) described a gas chromatography (GC)-MS system that successfully identified and quantified $\mathrm{HgBr}_{2}$ and $\mathrm{HgCl}_{2}$ in the laboratory, but this system had high detection limits and was unable to identify $\mathrm{Hg}$ compounds in ambient air. More work is needed to develop and refine MS-based methods, including and especially ambient air preconcentration methods that will work with MS systems.

The use of thermal desorption to identify oxidized mercury compounds in the atmosphere has also been explored (Gustin et al., 2016; Huang et al., 2017). In this technique, nylon membranes are used to collect mercury from ambient air, and membrane samples are then desorbed in a programmed temperature sequence, and desorbed mercury is passed through a pyrolyzer and analyzed for GEM. Oxidized mercury standards are loaded onto membranes and used to identify oxidized mercury compounds in the atmosphere. This method has shown that different oxidized mercury compounds exist in urban vs. rural atmospheres, at high versus lower elevation sites (Gustin et al., 2016), and at the same location at different times or seasons (Huang et al., 2017). Evidence for $\mathrm{HgBr}_{2}, \mathrm{HgCl}_{2}, \mathrm{HgO}$ and nitrogen- and sulfur-containing compounds has been produced via this method (Gustin et al., 2016; Huang et al., 2017). More work is needed to determine whether atmospheric constituents and conditions influence thermal desorption results.

No method has yet been developed that can quantitatively distinguish between GOM and PBM. This is a critical measurement need. A large portion of GOM can be lost on sample inlets that exclude large particles (Feng et al., 2003), and GOM can break through collection media and adhere to downstream filters that are intended for PBM collection (Lyman et al., 2016). GOM can adhere to inlets, tubing and fil- 
ters and later revolatilize, likely complicating the collection of PBM by filter-based methods (Lynam and Keeler, 2002, 2005; Pierce and Gustin, 2017; Rutter and Schauer, 2007; Talbot et al., 2011).

\subsection{Analysis and application of speciated mercury data}

Observations of speciated atmospheric $\mathrm{Hg}$ have been used in identifying $\mathrm{Hg}$ source-receptor relationships (Cheng et al., 2015a, and references therein), understanding $\mathrm{Hg}$ cycling, gas-particle partitioning and oxidation mechanisms (Amo et al., 2012; Cheng et al., 2014; Gabay et al., 2017; Obrist et al., 2011; Shah et al., 2016; Timonen et al., 2013; Ye et al., 2016), evaluating $\mathrm{Hg}$ transport models (Angot et al., 2016; Gustin et al., 2015; Kos et al., 2013; Weiss-Penzias et al., 2015) and quantifying $\mathrm{Hg}$ deposition budgets (Amo et al., 2012; Cheng et al., 2015b; Zhang et al., 2016b). Limited long-term data have also been applied in assessing $\mathrm{Hg}$ trends in the atmosphere and the effects of emission control policies (Brown et al., 2015; Castro and Sherwell, 2015; Cole et al., 2013, 2014; Martin et al., 2017; Steffen et al., 2005).

With an increasing geographical coverage of speciated $\mathrm{Hg}$ data, receptor-based source apportionment analysis has been utilized for quantifying contributions to the observed ambient $\mathrm{Hg}$ concentrations (Cheng et al., 2015a). Results generated from these analyses should be carefully compared to the results of source-based approaches, which may have the potential to improve natural emission inventories that can then be used in improving CTMs performance. This is because emission sources and intensities used in most CTMs are prepared using known anthropogenic sources and highly empirically parameterized natural sources (Pacyna et al., 2016), while receptor-based methods do not require comprehensive knowledge on source emissions and can predict potential sources. Existing emission inventories used in various CTMs should be compared in different model frameworks and with $\mathrm{Hg}$ speciation measurements (Pacyna et al., 2016).

CTMs were mostly evaluated using monitored wet deposition and total gaseous Hg (TGM) data (e.g., Gencarelli et al., 2017). These model simulations should be reassessed using available speciated $\mathrm{Hg}$ data as was done by Bieser et al. (2014), while keeping in mind the magnitude of potential uncertainties in the monitored $\mathrm{Hg}$ (Kos et al., 2013; Jaffe et al., 2014; Gustin et al., 2015; Cheng and Zhang, 2017). It is recommended that CTMs are evaluated over the Asian domain with high ambient oxidized $\mathrm{Hg}$ (and thus likely smaller uncertainties in oxidized $\mathrm{Hg}$ measurements), once monitoring data at multiple locations are available.

A major goal of monitoring speciated $\mathrm{Hg}$ in the $\mathrm{Na}$ tional Atmospheric Deposition Program (NADP) Atmospheric Mercury Network (AMNet) in North America is to provide reliable dry deposition estimation using the inferential modeling approach (Zhang et al., 2016b). However, uncertainties for fluxes estimated using this approach are likely larger than a factor of 2 , because of a lack of reliable flux data for developing and improving dry deposition algorithms. Different compounds of GOM will also have different dry deposition velocities (Huang et al., 2017). Intercomparison studies using multiple dry deposition algorithms should be conducted to provide a range of model uncertainties (Zhu et al., 2015a, b), and these model estimates should also be compared with other types of deposition measurements as mentioned in Sect. 2.2. Further development and/or improvement of the dry deposition algorithms are needed once new knowledge is gained.

Future work is needed to confirm the recently observed decreasing trend of TGM/GEM identified at a South Africa coastal site, over the Atlantic Ocean, at Canadian midlatitudinal sites and in China (Fu et al., 2015), and more work is needed to continue to unravel the causes for these decreasing trends. For example, changes in anthropogenic emissions likely played a major role in the changes of atmospheric Hg (Y. Zhang et al., 2016), while changes in marine boundary layer halogen chemistry (Parrella et al., 2012) and in riverine and wastewater discharges (Amos et al., 2014) were found to have little impact on mercury trends. The observed decreasing trends were likely to be associated with decreased re-emission of legacy mercury, changing anthropogenic emissions, reduced use of mercury in commercial products, enhanced oxidative capacity due to increasing tropospheric ozone, thus more production of GOM, and decreased evasion from the Atlantic Ocean. The last factor was thought to be driven by declining subsurface water $\mathrm{Hg}$ concentrations resulting from reduced $\mathrm{Hg}$ inputs from rivers and wastewater and from changes in the oxidant chemistry of the atmospheric marine boundary layer. These hypotheses require further research and validation using extensive, longerterm data sets and model results produced from simulations realistically representing dynamical, physical and chemical processes in mercury cycling in the atmosphere, the oceans and the terrestrial ecosystems, as well as the interactions among the three systems.

\subsection{Network harmonization}

Global distributions of tropospheric speciated $\mathrm{Hg}$ data remain sparse despite nearly 2 decades of extensive monitoring and modeling studies (Mao et al., 2016). Globally harmonized observation networks are needed for investigating intercontinental transport and providing mass balance estimation on a global scale. Measurement instruments, techniques, maintenance and standard operating procedures (SOPs) must be comparable between networks. In North America, the NADP/AMNet has utilized consistent measurement instrumentation, SOPs and data quality review across its 25 monitoring sites. The AMNet SOP was developed between 2007 and 2009 with the goal of developing one SOP and data quality assurance (QA) procedure generally agreed upon by the $\mathrm{Hg}$ research community (Gay et al., 2013; Steffen et al., 2012). This AMNet SOP and QA procedure was also adopted 
by the Global Mercury Observation System (GMOS) for use at its > 20 global sites (Sprovieri et al., 2016). Therefore, the two networks, GMOS and AMNet, are using very similar procedures to produce comparable observations of mercury.

Consistent quality control of mercury observations and quality assurance (QA/QC) processes after data collection is also necessary to ensure the data are generated consistently within and between operational networks. Among the operating Tekran-based atmospheric networks, both the Canadian Atmospheric Mercury Measurement Network (CAMNet) and the Atmospheric Mercury Network (NADP's AM$\mathrm{Net}$ ) in the US have data QA/QC systems in place. The two systems are reasonably comparable (Steffen et al., 2012), making the two network data sets comparable and usable in combination. In both cases, significant amounts of data are invalidated due to many different causes (e.g., Gay et al., 2013), clearly showing that post-measurement quality control is necessary. Additionally, the GMOS network also implemented a data quality control system (D'Amore et al., 2015) which is based upon both the Canadian and NADP systems and uses the majority of the flags from each system. A strict comparison between the three QC systems has not been completed but should be done in the near future. Based on the similarities in the data quality control procedures, it is at least reasonable to assume that the resulting data from the three networks are generally consistent. The QA/QC procedures from these three mercury monitoring networks provide a basis for the development of a global QA/QC process for all atmospheric observations, which is essential for the global modeling community using the data from the three networks.

Consistent and continuous measurements in Asia are particularly important since Asia is the largest source region for mercury emissions (Pacyna et al., 2016). The Asia Pacific Mercury Monitoring Network (APMMN) was developed to organize Asian countries into a network framework that will follow standard techniques for wet deposition monitoring (based on NADP methods), and ultimately the speciation measurement of ambient $\mathrm{Hg}$ (GEM, GOM and PBM). Although there have been continuous observational efforts in China in the past decade, a stronger coordination is recommended to avoid duplication of measurements and to enhance data quality consistence (Fu et al., 2016). Observational data in South Asia and the Middle East are particularly lacking. It is recommended to establish a harmonized monitoring network for data and procedure sharing in China and other Asian countries.

The value of consistent global measurements of atmospheric $\mathrm{Hg}$ concentrations will diminish without free exchange of data among scientists. As with AMNet, and planned with APMMN, all measurements should be validated using similar techniques, shared in organized databases, and released freely. This will allow modelers to use data for model evaluation, determination of locations with high concentrations, and provide data useful for scientists tracking mercury as it moves through the ecosys- tem. Furthermore, it will allow policy makers to determine whether mercury emission control achieves the desired deposition reduction of mercury compounds. Monitoring networks in regions other than the above-mentioned are also encouraged to fill data gaps in terms of spatial coverage on the global scale, particularly in Africa and South America.

Each atmospheric network has a different set of protocols on data release, but it would be very valuable to data users and the research community if freely available and timely data can be accessed from one location that applies a consistent quality assurance and control system to validate the data. Perhaps the operating networks will evolve to this combined operation, or perhaps some type of system similar to the GEOSS (Global Earth Observation System of Systems, https://www.earthobservations.org/geoss.php) could be employed, so that a consistent and global data set would be freely available to all data users.

It is conceivable that networks with large numbers of passive air sampling sites could complement existing networks for atmospheric mercury measurements using more sophisticated sampling techniques. Existing large-scale networks of passive air samplers at continental and global scales for organic contaminants (Gawor et al., 2014; Shen et al., 2004; Shunthirasingham et al., 2010) could serve as a template of what is feasible for gaseous mercury. Because of their low cost and limited operational requirements, passive air samplers could potentially play a role to increase the number of locations globally, although the comparison and interpretation of data obtained by different measurements require further research. Another research need is to establish the minimum change in long-term average concentrations that can be detected with passive sampling techniques, and what the best temporal resolution of such long-term monitoring should be.

Existing monitoring networks using the Tekran unit measure PBM at sizes $<2.5 \mu \mathrm{m}$. However, $\mathrm{Hg}$ in coarse particles could contribute substantially to the total $\mathrm{Hg}$ dry and wet deposition (Fang et al., 2012; Cheng et al., 2015b). Impactor measurements of total PBM in the marine boundary layer showed clear diurnal variations with daily maxima at around noon and minima before sunrise (Feddersen et al., 2012). In contrast, Tekran PBM measurement data from a limited number of marine boundary layer and continental monitoring locations worldwide exhibited no definitive diurnal patterns in PBM concentrations (Mao et al., 2016; Mao and Talbot, 2012), likely due to artifacts associated with the instrument's GOM and PBM measurements (Gustin et al., 2015). To understand and quantify atmospheric mercury deposition budgets and gas-particle partitioning, it is imperative to monitor $\mathrm{Hg}$ in both fine and coarse particles. 


\section{Conclusions}

Extensive field data of atmospheric mercury has been collected in the past several decades, and analysis and application of these data have generated a significant amount of knowledge regarding mercury sources, transport, chemical transformation and deposition. However, large uncertainties exist in almost every aspect related to atmospheric mercury cycling, inherited from those of the measurements especially in the oxidized forms of mercury due to their ultra-trace ambient concentrations, instrument limitations and undefined chemical speciation. Improving the accuracy of existing instruments and developing new technologies for routinely measuring speciated mercury is critically needed to provide high-quality data for further understanding of mercury cycling. Harmonized networks using the same operational and data quality control standards are strongly recommended for field data collection in various regions of the world. Box or 1-D numerical models with detailed chemistry combined with laboratory tests may shed light on possible chemical mechanisms controlling mercury cycling, while regional- to global-scale models should be further improved and evaluated using more recent data to provide a better constraint on mercury mass balance, and to improve emission and deposition budgets. Receptor-based models can be complementary to source-based models in improving emission estimation. Practical methods and instruments for surface flux measurements are needed to quantify natural emissions and dry deposition budgets, and existing algorithms estimating fluxes from these processes need further evaluation. Coordinated studies are strongly recommended for better integration of laboratory, field, and mathematical modeling research.

Data availability. No data sets were used in this article.

Competing interests. The authors declare that they have no conflict of interest.

Acknowledgements. We greatly appreciate all the co-authors who have contributed to the review papers published in the special issue of Atmospheric Chemistry and Physics (http://www.atmos-chem-phys.net/special_issue377.html), based on which this synthesis paper was produced.

Edited by: Ralf Ebinghaus

Reviewed by: two anonymous referees

\section{References}

Ambrose, J. L., Lyman, S. N., Huang, J., Gustin, M. S., and Jaffe, D. A.: Fast time resolution oxidized mercury measurements during the Reno Atmospheric Mercury Intercomparison Experiment (RAMIX), Environ. Sci. Technol., 47, 7285-7294, 2013.

Ambrose, J. L., Gratz, L. E., Jaffe, D. A., Campos, T., Flocke, F. M., Knapp, D. J., Stechman, D. M., Stell, M., Weinheimer, A. J., and Cantrell, C. A.: Mercury emission ratios from coal-fired power plants in the Southeastern United States during NOMADSS, Environ. Sci. Technol., 49, 10389-10397, 2015.

Amos, H. M., Jacob, D. J., Holmes, C. D., Fisher, J. A., Wang, Q., Yantosca, R. M., Corbitt, E. S., Galarneau, E., Rutter, A. P., Gustin, M. S., Steffen, A., Schauer, J. J., Graydon, J. A., St. Louis, V. L., Talbot, R. W., Edgerton, E. S., Zhang, Y., and Sunderland, E. M.: Gas-particle partitioning of atmospheric $\mathrm{Hg}(\mathrm{II})$ and its effect on global mercury deposition, Atmos. Chem. Phys., 12, 591-603, https://doi.org/10.5194/acp-12-5912012, 2012.

Amos, H. M., Jacob, D. J., Kocman, D., Horowitz, H. M., Zhang, Y., Dutkiewicz, S., Horvat, M., Corbitt, E. S., Krabbenhoft, D. P., and Sunderland, E. M.: Global biogeochemical implications of mercury discharges from rivers and sediment burial, Environ. Sci. Technol., 48, 9514-9522, 2014.

Angot, H., Dastoor, A., De Simone, F., Gårdfeldt, K., Gencarelli, C. N., Hedgecock, I. M., Langer, S., Magand, O., Mastromonaco, M. N., Nordstrøm, C., Pfaffhuber, K. A., Pirrone, N., Ryjkov, A., Selin, N. E., Skov, H., Song, S., Sprovieri, F., Steffen, A., Toyota, K., Travnikov, O., Yang, X., and Dommergue, A.: Chemical cycling and deposition of atmospheric mercury in polar regions: review of recent measurements and comparison with models, Atmos. Chem. Phys., 16, 10735-10763, https://doi.org/10.5194/acp-16-10735-2016, 2016.

Ariya, P. A., Amyot, M., Dastoor, A., Deeds, D., Feinberg, A., Kos, G., Poulain, A., Ryjkov, A., Semeniuk, K., Subir, M., and Toyota, K.: Mercury Physicochemical and Biogeochemical Transformation in the Atmosphere and at Atmospheric Interfaces: A Review and Future Directions, Chem. Rev., 115, 3760-3802, 2015.

Balabanov, N. B., Shepler, B. C., and Peterson, K. A.: Accurate Global Potential Energy Surface and Reaction Dynamics for the Ground State of $\mathrm{HgBr}_{2}$, J. Phys. Chem. A, 109, 8765-8773, 2005.

Bieser, J., De Simone, F., Gencarelli, C., Geyer, B., Hedgecock, I., Matthias, V., Travnikov, O., and Weigelt, A.: A diagnostic evaluation of modeled mercury wet depositions in Europe using atmospheric speciated high-resolution observations, Environ. Sci. Poll. Res., 21, 9995-10012, 2014.

Blum, J. D. and Johnson, M. W.: Recent Developments in Mercury Stable Isotope Analysis, in: Non-Traditional Stable Isotopes, edited by: Teng, F. Z., Watkins, J., Dauphas, N., Mineralogical Soc. Amer. \& Geochemical. Soc., Chantilly, 733-757, 2017.

Briggs, C. and Gustin, M. S.: Building upon the conceptual model for soil mercury flux: Evidence of a link between moisture evaporation and $\mathrm{Hg}$ evasion, Water Air Soil Poll., 224, 1744, https://doi.org/10.1007/s11270-013-1744-5, 2013.

Brown, R. J. C., Goddard, S. L., Butterfield, D. M., Brown, A. S., Robins, C., Mustoe, C. L., and McGhee, E. A.:. Ten years of mercury measurement at urban and industrial air quality monitoring stations in the UK, Atmos. Environ., 109, 1-8, 2015. 
Calvert, J. G. and Lindberg, S. E.: Mechanisms of mercury removal by $\mathrm{O}_{3}$ and $\mathrm{OH}$ in the atmosphere, Atmos. Environ., 39, 33553367, 2005.

Castro, M. S. and Sherwell, J.: Effectiveness of emission controls to reduce the atmospheric concentrations of mercury, Environ. Sci. Technol., 49, 14000-14007, 2015.

Cheng, I. and Zhang, L.: Uncertainty assessment of gaseous oxidized mercury measurements collected by Atmospheric Mercury Network, Environ. Sci. Technol., 51, 855-862, 2017.

Cheng, I., Zhang, L., and Blanchard, P.: Regression modeling of gas-particle partitioning of atmospheric oxidized mercury from temperature data, J. Geophys. Res.-Atmos., 119, 11864-11876, 2014.

Cheng, I., Xu, X., and Zhang, L.: Overview of receptorbased source apportionment studies for speciated atmospheric mercury, Atmos. Chem. Phys., 15, 7877-7895, https://doi.org/10.5194/acp-15-7877-2015, 2015a.

Cheng, I., Zhang, L., and Mao, H.: Relative contributions of gaseous oxidized mercury and fine and coarse particle-bound mercury to mercury wet deposition at nine monitoring sites in North America, J. Geophys. Res.-Atmos., 120, 8549-8562, 2015 b.

Cole, A. S., Steffen, A., Pfaffhuber, K. A., Berg, T., Pilote, M., Poissant, L., Tordon, R., and Hung, H.: Ten-year trends of atmospheric mercury in the high Arctic compared to Canadian subArctic and mid-latitude sites, Atmos. Chem. Phys., 13, 15351545, https://doi.org/10.5194/acp-13-1535-2013, 2013.

Cole, A. S., Steffen, A., Eckley, C. S., Narayan, J., Pilote, M., Tordon, R., Graydon, J. A., St Louis, V. L., Xu, X., and Branfireun, B. A.: A survey of mercury in air and precipitation across canada: Patterns and trends, Atmosphere, 5, 635-668, 2014.

D’Amore, F., Bencardino, M., Cinnirella, S., Sprovieri, F., and Pirrone, N.: Data quality through a web-based QA/QC system: implementation for atmospheric mercury data from the Global Mercury Observation System, Environ. Sci. Proc. Impacts, 17, 14821491, 2015.

Deeds, D. A., Ghoshdastidar, A., Raofie, F., Gueìrette, E.-A., Tessier, A., and Ariya, P. A.: Development of a Particle-Trap Preconcentration-Soft Ionization Mass Spectrometric Technique for the Quantification of Mercury Halides in Air, Anal. Chem., 87, 5109-5116, 2015.

De Simone, F., Gencarelli, C. N., Hedgecock, I. M., and Pirrone, N.: Global atmospheric cycle of mercury: A model study on the impact of oxidation mechanisms, Environ. Sci. Poll. Res., 21, 4110-4123, 2014.

Dibble, T. S., Zelie, M. J., and Mao, H.: Thermodynamics of reactions of $\mathrm{ClHg}$ and $\mathrm{BrHg}$ radicals with atmospherically abundant free radicals, Atmos. Chem. Phys., 12, 10271-10279, https://doi.org/10.5194/acp-12-10271-2012, 2012.

ECCC - Environmental and Climate Change Canada: Canadian Mercury Science Assessment, edited by: Steffen, A., Ottawa, Canada, 2017.

Eckley, C. S., Gustin, M., Miller, M. B., and Marsik, F.: Scaling of nonpoint source $\mathrm{Hg}$ emissions from active industrial gold minesinfluential variables and annual emission estimates, Environ. Sci. Technol., 45, 392-399, 2011.

Eckley, C. S., Tate, M. T., Lin, C.-J., Gustin, M., Dent, S., EaglesSmith, C., Lutz, M. A., Wickland, K. P., Wang, B., Gray, J. E., Edwards, G. C., Krabbenhoft, D. P., and Smith, D. B.: Surfaceair mercury fluxes across Western North America: A synthesis of spatial trends and controlling variables, Sci. Total Environ., 568, 651-665, 2016.

Edwards, G. C. and Howard, D. A.: air-surface exchange measurements of gaseous elemental mercury over naturally enriched and background terrestrial landscapes in Australia, Atmos. Chem. Phys., 13, 5325-5336, https://doi.org/10.5194/acp13-5325-2013, 2013.

Ericksen, J. A., Gustin, M. S., Xin, M., and Fernandez, G. C. J.: Air soil exchange of mercury from background soils in the United States, Sci. Total Environ., 366, 851-863, 2006.

Fang, G. C., Zhang, L., and Huang, C. S.: Measurements of sizefractionated concentration and bulk dry deposition of atmospheric particulate bound mercury, Atmos. Environ., 61, 371377, 2012.

Feddersen, D. M., Talbot, R., Mao, H., and Sive, B. C.: Size distribution of particulate mercury in marine and coastal atmospheres, Atmos. Chem. Phys., 12, 10899-10909, https://doi.org/10.5194/acp-12-10899-2012, 2012.

Feng, X., Lu, J. Y., Hao, Y., Banic, C., and Schroeder, W. H.: Evaluation and applications of a gaseous mercuric chloride source, Anal. Bioanal. Chem., 376, 1137-1140, 2003.

Finley, B. D., Jaffe, D. A., Call, K., Lyman, S., Gustin, M. S., Peterson, C., Miller, M., and Lyman, T.: Development, testing, and deployment of an air sampling manifold for spiking elemental and oxidized mercury during the Reno Atmospheric Mercury Intercomparison Experiment (RAMIX), Environ. Sci. Technol., 47, 7277-7284, 2013.

Friedli, H. R., Radke, L. F., Lu, J. Y., Banic, C. M., Leaitch, W. R., and MacPherson, J. I.: Mercury emissions from burning of biomass from temperate North American forests: Laboratory and airborne measurements, Atmos. Environ., 37, 253-267, 2003.

Friedli, H. R., Arellano, A. F., Cinnirella, S., and Pirrone, N.: Initial estimates of mercury emissions to the atmosphere from global biomass burning, Environ. Sci. Technol., 43, 3507-3513, 2009.

Fu, X. W., Zhang, H., Yu, B., Wang, X., Lin, C.-J., and Feng, X. B.: Observations of atmospheric mercury in China: a critical review, Atmos. Chem. Phys., 15, 9455-9476, https://doi.org/10.5194/acp-15-9455-2015, 2015.

Fu, X. W., Marusczak, N., Wang, X., Gheusi, F., and Sonke, J. E.: Isotopic composition of gaseous elemental mercury in the free troposphere of the Pic du Midi Observatory, France, Environ. Sci. Technol., 50, 5641-5650, 2016.

Gabay, M., Peleg, M., Fredj, E., and Tas, E.: Measurementbased modeling of daytime and nighttime oxidation of atmospheric mercury, Atmos. Chem. Phys. Discuss., https://doi.org/10.5194/acp-2017-39, in review, 2017.

Gawor, A., Shunthirasingham, C., Hayward, S. J., Lei, Y. D., Gouin, T., Mmereki, B. T., Masamba, W., Ruepert, C., Castillo, L. E., Lee, S. C., Shoeib, M., Harner, T., and Wania, F.: Neutral perfluoroalkyl substances in the global atmosphere, Environ. Sci. Proc. Impacts, 16, 404-413, 2014.

Gay, D. A., Schmeltz, D., Prestbo, E., Olson, M., Sharac, T., and Tordon, R.: The Atmospheric Mercury Network: measurement and initial examination of an ongoing atmospheric mercury record across North America, Atmos. Chem. Phys., 13, 1133911349, https://doi.org/10.5194/acp-13-11339-2013, 2013.

Gencarelli, C. N., Bieser, J., Carbone, F., De Simone, F., Hedgecock, I. M., Matthias, V., Travnikov, O., Yang, X., and Pirrone, N.: Sensitivity model study of regional mercury disper- 
sion in the atmosphere, Atmos. Chem. Phys., 17, 627-643, https://doi.org/10.5194/acp-17-627-2017, 2017.

Gratz, L., Ambrose, J., Jaffe, D., Shah, V., Jaeglé, L., Stutz, J., Festa, J., Spolaor, M., Tsai, C., and Selin, N.: Oxidation of mercury by bromine in the subtropical Pacific free troposphere, Geophys. Res. Lett., 42, 10494-10502, 2015.

Graydon, J. A., St. Louis, V. L., Lindberg, S. E., Sandilands, K. A., Rudd, J. W. M., Kelly, C. A., Harris, R., Tate, M. T., Krabbenhoft, D. P., Emmerton, C. A., Asmath, H., and Richardson, M.: The role of terrestrial vegetation in atmospheric $\mathrm{Hg}$ deposition: Pools and fluxes of spike and ambient $\mathrm{Hg}$ from the METAALICUS experiment, Global Biogeochem. Cy., 26, 1022, https://doi.org/10.1029/2011GB004031, 2012.

Gustin, M. S.: Exchange of Mercury between the Atmosphere and Terrestrial Ecosystems, in: chap. 13 in Environmental Chemistry and Toxicology of Mercury edited by: Liu, G., Cai, Y., and O'driscoll, N.,John Wiley and Sons, https://doi.org/10.1002/9781118146644.ch13, 2011.

Gustin, M. S., Huang, J., Miller, M. B., Peterson, C., Jaffe, D. A., Ambrose, J., Finley, B. D., Lyman, S. N., Call, K., and Talbot, R.: Do we understand what the mercury speciation instruments are actually measuring? Results of RAMIX, Environ. Sci. Technol., 47, 7295-7306, 2013.

Gustin, M. S., Amos, H. M., Huang, J., Miller, M. B., and Heidecorn, K.: Measuring and modeling mercury in the atmosphere: a critical review, Atmos. Chem. Phys., 15, 5697-5713, https://doi.org/10.5194/acp-15-5697-2015, 2015.

Gustin, M. S., Pierce, A. M., Huang, J., Miller, M. B., Holmes, H., and Loria-Salazar, S. M.: Evidence for different reactive $\mathrm{Hg}$ sources and chemical compounds at adjacent valley and high elevation locations, Environ. Sci. Technol., 50, 12225-12231, 2016.

Hartman, J., Weisberg, P., Pillai, R., Ericksen, J. A., Kuiken, T., Lindberg, S., Zhang, H., Rytuba, J., and Gustin, M. S.: Application of a rule-based model to estimate mercury exchange for three background biomes in the continental United States, Environ. Sci. Technol., 43, 4989-4994, 2009.

Horowitz, H. M., Jacob, D. J., Zhang, Y., Dibble, T. S., Slemr, F., Amos, H. M., Schmidt, J. A., Corbitt, E. S., Marais, E. A., and Sunderland, E. M.: A new mechanism for atmospheric mercury redox chemistry: implications for the global mercury budget, Atmos. Chem. Phys., 17, 6353-6371, https://doi.org/10.5194/acp17-6353-2017, 2017.

Huang, J. and Gustin, M. S.: Uncertainties of Gaseous Oxidized Mercury Measurements Using KCl-Coated Denuders, CationExchange Membranes, and Nylon Membranes: Humidity Influences, Environ. Sci. Technol., 49, 6102-6108, 2015.

Huang, J., Miller, M. B., Weiss-Penzias, P., and Gustin, M. S.: Comparison of gaseous oxidized $\mathrm{Hg}$ measured by $\mathrm{KCl}$-coated denuders, and nylon and cation exchange membranes, Environ. Sci. Technol., 47, 7307-7316, 2013.

Huang, J., Lyman, S. N., Stamenkovic Hartman, J., and Gustin, M. S.: A review of Passive sampling systems for ambient air mercury measurements, Environ. Sci. Proc. Impacts, 16, 374-392, 2014.

Huang, J., Miller, M. B., Edgerton, E., and Sexauer Gustin, M.: Deciphering potential chemical compounds of gaseous oxidized mercury in Florida, USA, Atmos. Chem. Phys., 17, 1689-1698, https://doi.org/10.5194/acp-17-1689-2017, 2017.
Jaffe, D. A., Lyman, S., Amos, H. M., Gustin, M. S., Huang, J., Selin, N. E., Leonard, L., ter Schure A., Mason, R. P., Talbot, R., Rutter, A., Finley, B., Jaeglé, L., Shah, V., McClure, C., Ambrose, J., Gratz, L., Lindberg, S., Weiss-Penzias, P., Sheu, G. R., Feddersen, D., Horvat, M., Dastoor, A., Hynes, A. J., Mao, H., Sonke, J. E., Slemr, F., Fisher, J. A., Ebinghaus, R., Zhang, Y., and Edwards, G.: Progress on understanding atmospheric mercury hampered by uncertain measurements, Environ. Sci. Technol., 48, 7204-7206, 2014.

Jiao, Y. and Dibble, T. S.: First kinetic study of the atmospherically important reactions $\mathrm{BrHg}+\mathrm{NO}_{2}$ and $\mathrm{BrHg}+\mathrm{HOO}$, Phys. Chem. Chem. Phys., 19, 1826-1838, 2017.

Jones, C. P., Lyman, S. N., Jaffe, D. A., Allen, T., and O’Neil, T. L.: Detection and quantification of gas-phase oxidized mercury compounds by GC/MS, Atmos. Meas. Tech., 9, 2195-2205, https://doi.org/10.5194/amt-9-2195-2016, 2016.

Kocman, D., Wilson, S. J., Amos, H. M., Telmer, K. H., Steenhuisen, F., Sunderland, E. M., Mason, R. P., Outridge, P., and Horvat, M.: Toward an assessment of the global inventory of present-day mercury releases to freshwater environments, Int. J. Environ. Res. Publ. Health, 14, 138, https://doi.org/10.3390/ijerph14020138, 2017.

Kos, G., Ryzhkov, A., Dastoor, A., Narayan, J., Steffen, A., Ariya, P. A., and Zhang, L.: Evaluation of discrepancy between measured and modelled oxidized mercury species, Atmos. Chem. Phys., 13, 4839-4863, https://doi.org/10.5194/acp13-4839-2013, 2013.

Lin, C. J., Pongprueksa, P., Lindberg, S. E., Pehkonen, S. O., Byun, D., and Jang, C.: Scientific uncertainties in atmospheric mercury models I: Model science evaluation, Atmos. Environ., 40, 29112928, 2006.

Liu, M., Zhang, W., Wang, X., Chen, L., Wang, H., Luo, Y., Zhang, H., Shen, H., Tong, Y., Ou, L., Xie, H., Ye, X., and Deng, C.: Mercury release to aquatic environments from anthropogenic sources in China from 2001 to 2012, Environ. Sci. Technol., 50, 8169-8177, 2016.

Lyman, S. N. and Jaffe, D. A.: Elemental and oxidized mercury in the upper troposphere and lower stratosphere, Nat. Geosci., 5, 114-117, 2012.

Lyman, S. N., Gustin, M. S., Prestbo, E. M., and Marsik, F. J.: Estimation of Dry Deposition of Atmospheric Mercury in Nevada by Direct and Indirect Methods, Environ. Sci. Technol., 41, 19701976, 2007.

Lyman, S. N., Jaffe, D. A., and Gustin, M. S.: Release of mercury halides from $\mathrm{KCl}$ denuders in the presence of ozone, Atmos. Chem. Phys., 10, 8197-8204, https://doi.org/10.5194/acp10-8197-2010, 2010.

Lyman, S., Jones, C., O’Neil, T., Allen, T., Miller, M., Gustin, M. S., Pierce, A. M., Luke, W., Ren, X., and Kelley, P.: Automated Calibration of Atmospheric Oxidized Mercury Measurements, Environ. Sci. Technol., 50, 12921-12927, 2016.

Lynam, M. M. and Keeler, G. J.: Comparison of methods for particulate phase mercury analysis: sampling and analysis, Anal. Bioanal. Chem., 374, 1009-1014, 2002.

Lynam, M. M. and Keeler, G. J.: Artifacts associated with the measurement of particulate mercury in an urban environment: The influence of elevated ozone concentrations, Atmos. Environ., 39, 3081-3088, 2005. 
Mao, H. and Talbot, R.: Speciated mercury at marine, coastal, and inland sites in New England - Part 1: Temporal variability, Atmos. Chem. Phys., 12, 5099-5112, https://doi.org/10.5194/acp12-5099-2012, 2012.

Mao, H., Cheng, I., and Zhang, L.: Current understanding of the driving mechanisms for spatiotemporal variations of atmospheric speciated mercury: a review, Atmos. Chem. Phys., 16, 1289712924, https://doi.org/10.5194/acp-16-12897-2016, 2016.

Martin, L. G., Labuschagne, C., Brunke, E.-G., Weigelt, A., Ebinghaus, R., and Slemr, F.: Trend of atmospheric mercury concentrations at Cape Point for 1995-2004 and since 2007, Atmos. Chem. Phys., 17, 2393-2399, https://doi.org/10.5194/acp17-2393-2017, 2017.

McClure, C. D., Jaffe, D. A., and Edgerton, E. S.: Evaluation of the $\mathrm{KCl}$ denuder method for gaseous oxidized mercury using $\mathrm{HgBr} 2$ at an in-service AMNet site, Environ. Sci. Technol., 48, 1143711444, 2014.

McLagan, D. S., Mazur, M. E. E., Mitchell, C. P. J., and Wania, F.: Passive air sampling of gaseous elemental mercury: a critical review, Atmos. Chem. Phys., 16, 3061-3076, https://doi.org/10.5194/acp-16-3061-2016, 2016.

Miller, M. B. and Gustin, M. S.: Testing and modeling the influence of reclamation and control methods for reducing non-point mercury emissions associated with industrial open pit gold mines, J. Air Waste Manage. Assoc., 63, 681-693, https://doi.org/10.1080/10962247.2013.778221, 2013.

Miller, M. B., Gustin, M. S., and Eckley, C.: Measurement and Scaling of air-surface exchange from substrates in the vicinity of two Nevada gold mines, Sci. Total Environ., 409, 3879-3866, 2011.

Obrist, D., Tas, E., Peleg, M., Matveev, V., Faïn, X., Asaf, D., and Luria, M.: Bromine-induced oxidation of mercury in the midlatitude atmosphere, Nat. Geosci., 4, 22-26, 2011.

Osterwalder, S., Fritsche, J., Alewell, C., Schmutz, M., Nilsson, M. B., Jocher, G., Sommar, J., Rinne, J., and Bishop, K.: A dualinlet, single detector relaxed eddy accumulation system for longterm measurement of mercury flux, Atmos. Meas. Tech., 9, 509524, https://doi.org/10.5194/amt-9-509-2016, 2016.

Pacyna, J. M., Travnikov, O., Simone, F. D., Hedgecock, I. M., Sundseth, K., Pacyna, E. G., Steenhuisen, F., Pirrone, N., Munthe, J., and Kindbom, K.: Current and future levels of mercury atmospheric pollution on a global scale, Atmos. Chem. Phys., 16, 12495-12511, https://doi.org/10.5194/acp-16-124952016, 2016.

Parrella, J. P., Jacob, D. J., Liang, Q., Zhang, Y., Mickley, L. J., Miller, B., Evans, M. J., Yang, X., Pyle, J. A., Theys, N., and Van Roozendael, M.: Tropospheric bromine chemistry: implications for present and pre-industrial ozone and mercury, Atmos. Chem. Phys., 12, 6723-6740, https://doi.org/10.5194/acp12-6723-2012, 2012.

Pierce, A. M. and Gustin, M. S.: Development of a Particulate Mass Measurement System for Quantification of Ambient Reactive Mercury, Environ. Sci. Technol., 51, 436-445, 2017.

Pongprueksa, P., Lin, C. J., Lindberg, S. E., Jang, C., Braverman, T., Russell Bullock Jr., O., Ho, T. C., and Chu, H. W.: Scientific uncertainties in atmospheric mercury models III: Boundary and initial conditions, model grid resolution, and $\mathrm{Hg}$ (II) reduction mechanism, Atmos. Environ., 42, 1828-1845, 2008.
Rutter, A. P. and Schauer, J. J.: The effect of temperature on the gasparticle partitioning of reactive mercury in atmospheric aerosols, Atmos. Environ., 41, 8647-8657, 2007.

Rutter, A. P., Hanford, K. L., Zwers, J. T., Perillo-Nicholas, A. L., Schauer, J. J., and Olson, M. L.: Evaluation of an offline method for the analysis of atmospheric reactive gaseous mercury and particulate mercury, J. Air Waste Manage. Assoc., 58, 377-383, 2008.

Shah, V., Jaeglé, L., Gratz, L. E., Ambrose, J. L., Jaffe, D. A., Selin, N. E., Song, S., Campos, T. L., Flocke, F. M., Reeves, M., Stechman, D., Stell, M., Festa, J., Stutz, J., Weinheimer, A. J., Knapp, D. J., Montzka, D. D., Tyndall, G. S., Apel, E. C., Hornbrook, R. S., Hills, A. J., Riemer, D. D., Blake, N. J., Cantrell, C. A., and Mauldin III, R. L.: Origin of oxidized mercury in the summertime free troposphere over the southeastern US, Atmos. Chem. Phys., 16, 1511-1530, https://doi.org/10.5194/acp16-1511-2016, 2016.

Shen, L., Wania, F., Lei, Y. D., Teixeira, C., Muir, D. C. G., and Bidleman, T. F.: Hexachlorocyclohexanes in the North American atmosphere, Environ. Sci. Technol., 38, 965-975, 2004.

Shunthirasingham, C., Oyiliagu, C. E., Cao, X. S., Gouin, T., Wania, F., Lee, S.-C., Pozo, K., Harner, T., and Muir, D. C. G.: Spatial and temporal pattern of pesticides in the global atmosphere, J. Environ. Monitor., 12, 1650-1657, 2010.

Skov, H., Brooks S.B., Goodsite M.E., Lindberg S.E., Meyers T.P., Landis M.S., Larsen M.R.B., and Christensen J.: Fluxes of reactive gaseous mercury measured with a newly developed method using relaxed eddy accumulation. Atmos. Environ. 40, 54525463, 2006.

Slemr, F., Weigelt, A., Ebinghaus, R., Kock, H. H., Bödewadt, J., Brenninkmeijer, C. A. M., Rauthe-Schöch, A., Weber, S., Hermann, M., Becker, J., Zahn, A., and Martinsson, B.: Atmospheric mercury measurements onboard the CARIBIC passenger aircraft, Atmos. Meas. Tech., 9, 2291-2302, https://doi.org/10.5194/amt-9-2291-2016, 2016.

Solis, K. L. B., Nam, G., and Hong, Y.: Mercury(II) reduction and sulfite oxidation in aqueous systems: Kinetics study and speciation modeling, Environ. Chem., 14, 151-159, 2017.

Sprovieri, F., Pirrone, N., Bencardino, M., D’Amore, F., Carbone, F., Cinnirella, S., Mannarino, V., Landis, M., Ebinghaus, R., Weigelt, A., Brunke, E.-G., Labuschagne, C., Martin, L., Munthe, J., Wängberg, I., Artaxo, P., Morais, F., Barbosa, H. D. M. J., Brito, J., Cairns, W., Barbante, C., Diéguez, M. D. C., Garcia, P. E., Dommergue, A., Angot, H., Magand, O., Skov, H., Horvat, M., Kotnik, J., Read, K. A., Neves, L. M., Gawlik, B. M., Sena, F., Mashyanov, N., Obolkin, V., Wip, D., Feng, X. B., Zhang, H., Fu, X., Ramachandran, R., Cossa, D., Knoery, J., Marusczak, N., Nerentorp, M., and Norstrom, C.: Atmospheric mercury concentrations observed at groundbased monitoring sites globally distributed in the framework of the GMOS network, Atmos. Chem. Phys., 16, 11915-11935, https://doi.org/10.5194/acp-16-11915-2016, 2016.

Steffen, A., Schroeder, W., Macdonald, R., Poissant, L., and Konoplev, A.: Mercury in the Arctic atmosphere: An analysis of eight years of measurements of GEM at Alert (Canada) and a comparison with observations at Amderma (Russia) and Kuujjuarapik (Canada), Sci. Total Environ., 342, 185-198, 2005.

Steffen, A., Scherz, T., Olson, M., Gay, D., and Blanchard, P.: A comparison of data quality control protocols for atmospheric 
mercury speciation measurements, J. Environ. Monitor., 14, 752$765,2012$.

Subir, M., Ariya, P. A., and Dastoor, A. P.: A review of uncertainties in atmospheric modeling of mercury chemistry I. Uncertainties in existing kinetic parameters - Fundamental limitations and the importance of heterogeneous chemistry, Atmos. Environ., 45, 5664-5676, 2011.

Subir, M., Ariya, P. A., and Dastoor, A. P.: A review of the sources of uncertainties in atmospheric mercury modeling II. Mercury surface and heterogeneous chemistry - A missing link, Atmos. Environ., 46, 1-10, 2012.

Sun, G. Y., Sommar, J., Feng, X. B., Lin, C.-J., Ge, M. F., Wang, W. G., Yin, R. S., Fu, X. W., and Shang, L. H.: Mass-Dependent and -Independent Fractionation of Mercury Isotope during GasPhase Oxidation of Elemental Mercury Vapor by Atomic $\mathrm{Cl}$ and Br, Environ. Sci. Technol., 50, 9232-9241, 2016.

Sun, R., Streets, D. G., Horowitz, H. M., Amos, H. M., Liu, G., Perrot, V., Toutain, J.-P., Hintelmann, H., Sunderland, E. M., and Sonke, J. E.: Historical (18502010) mercury stable isotope inventory from anthropogenic sources to the atmosphere, Elementa, 4, 000091, https://doi.org/10.12952/journal.elementa.000091, 2016.

Talbot, R., Mao, H., Feddersen, D., Smith, M., Kim, S. Y., Sive, B., Haase, K., Ambrose, J., Zhou, Y., and Russo, R.: Comparison of Particulate Mercury Measured with Manual and Automated Methods, Atmosphere, 2, 1-20, 2011.

Timonen, H., Ambrose, J. L., and Jaffe, D. A.: Oxidation of elemental $\mathrm{Hg}$ in anthropogenic and marine airmasses, Atmos. Chem. Phys., 13, 2827-2836, https://doi.org/10.5194/acp-132827-2013, 2013.

UNEP - United Nations Environment Programme: Global Mercury Assessment 2013: Sources, Emissions, Releases and Environmental Transport, UNEP Chemicals Branch, Geneva, Switzerland, 2013.

Urba, A., Valiulis, D., Šarlauskas, J., Kvietkus, K., Šakalys, J., and Selskis, A.: A pilot study of different materials applied for active sampling of gaseous oxidized mercury in the atmospheric air, Atmos. Poll. Res., 8, 791-799, 2017.

Wang, X., Lin, C.-J., Lu, Z., Zhang, H., Zhang, Y., and Feng, X.: Enhanced accumulation and storage of mercury on subtropical evergreen forest floor: Implications on mercury budget in global forest ecosystems, J. Geophys. Res.-Biogeo., 121, 2096-2109, https://doi.org/10.1002/2016JG003446, 2016.

Webster, J. P., Kane, T. J., Obrist, D., Ryan, J. N., and Aiken, G. R.: Estimating mercury emissions resulting from wildfire in forests of the Western United States, Sci. Total Environ., 568, 578-586, 2016.

Weiss-Penzias, P., Amos, H. M., Selin, N. E., Gustin, M. S., Jaffe, D. A., Obrist, D., Sheu, G.-R., and Giang, A.: Use of a global model to understand speciated atmospheric mercury observations at five high-elevation sites, Atmos. Chem. Phys., 15, 11611173, https://doi.org/10.5194/acp-15-1161-2015, 2015.
Wright, L. P., Zhang, L., and Marsik, F. J.: Overview of mercury dry deposition, litterfall, and throughfall studies, Atmos. Chem. Phys., 16, 13399-13416, https://doi.org/10.5194/acp-16-133992016, 2016.

Wu, Z. Y., Zhang, L., Wang, X. M., and Munger, J. W.: A modified micrometeorological gradient method for estimating $\mathrm{O}_{3}$ dry depositions over a forest canopy, Atmos. Chem. Phys., 15, 74877496, https://doi.org/10.5194/acp-15-7487-2015, 2015.

Ye, Z., Mao, H., Lin, C.-J., and Kim, S. Y.: Investigation of processes controlling summertime gaseous elemental mercury oxidation at midlatitudinal marine, coastal, and inland sites, Atmos. Chem. Phys., 16, 8461-8478, https://doi.org/10.5194/acp16-8461-2016, 2016.

Ye, Z., Mao, H., Driscoll, C. T., Wang, Y., Hogrefe, C., Volkamer, R., Zhang, Y., and Jaegle, L.: Evaluation of CMAQ Coupled with a State-of-the-Art Mercury Chemical Mechanism (CMAQnewHg-Br), J. Adv. Model. Earth Syst., submitted, 2017.

Yu, B., Fu, X., Yin, R., Zhang, H., Wang, X., Lin, C.-J., Wu, C., Zhang, Y., He, N., Fu, P., Wang, Z., Shang, L., Sommar, J., Sonke, J. E., Maurice, L., Guinot, B., and Feng, X.: Isotopic composition of atmospheric mercury in China: New evidence for sources and transformation processes in air and in vegetation, Environ. Sci. Technol., 50, 9362-9369, 2016.

Zhang, L., Wang, S., Wu, Q., Wang, F., Lin, C.-J., Zhang, L., Hui, M., Yang, M., Su, H., and Hao, J.: Mercury transformation and speciation in flue gases from anthropogenic emission sources: a critical review, Atmos. Chem. Phys., 16, 2417-2433, https://doi.org/10.5194/acp-16-2417-2016, 2016a.

Zhang, L., Wu, Z., Cheng, I., Wright, L. P., Olson, M. L., Gay, D. A., Risch, M. R., Brooks, S., Castro, M. S., Conley, G. D., Edgerton, E. S., Holsen, T. M., Luke, W., Tordon, R., and Weiss-Penzias, P.: The estimated six-year mercury dry deposition across North America, Environ. Sci. Technol., 50, 12864-12873, 2016b.

Zhang, Y., Jacob, D. J., Horowitz, H. M., Chen, L., Amos, H. M., Krabbenhoft, D. P., Slemr, F., St Louis, V. L., and Sunderland, E. M.: Observed decrease in atmospheric mercury explained by global decline in anthropogenic emissions, P. Natl. Acad. Sci. USA, 113, 526-531, 2016.

Zhu, W., Sommar, J., Lin, C.-J., and Feng, X.: Mercury vapor air-surface exchange measured by collocated micrometeorological and enclosure methods - Part I: Data comparability and method characteristics, Atmos. Chem. Phys., 15, 685-702, https://doi.org/10.5194/acp-15-685-2015, 2015a.

Zhu, W., Sommar, J., Lin, C.-J., and Feng, X.: Mercury vapor air-surface exchange measured by collocated micrometeorological and enclosure methods - Part II: Bias and uncertainty analysis, Atmos. Chem. Phys., 15, 5359-5376, https://doi.org/10.5194/acp-15-5359-2015, 2015b.

Zhu, W., Lin, C.-J., Wang, X., Sommar, J., Fu, X., and Feng, X.: Global observations and modeling of atmosphere-surface exchange of elemental mercury: a critical review, Atmos. Chem. Phys., 16, 4451-4480, https://doi.org/10.5194/acp-164451-2016, 2016. 